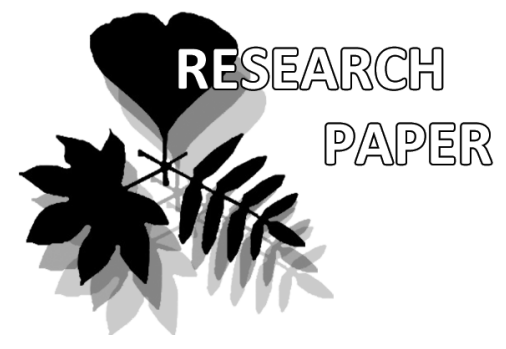

\title{
Moss diversity distribution patterns and agglomerates of local floras in the Russian Far East
}

Olga Yu. Pisarenko ${ }^{1 *}$

e-mail: o_pisarenko@mail.ru

Vadim A. Bakalin ${ }^{2}$

e-mail: vabakalin@gmail.com

${ }^{1}$ Central Siberian Botanical Garden, SB RAS, Novosibirsk 630090 Russia

${ }^{2}$ Botanical Garden-Institute FEB RAS, Vladivostok 690024 Russia

* corresponding author

Manuscript received: 17.02.2017

Review completed: 13.09.2017

Accepted for publication: 18.09.2017

Published online: 19.09.2017

\author{
Olga Yu. Pisarenko ${ }^{1 *} \&$ Vadim A. Bakalin ${ }^{2}$
}

\begin{abstract}
A B S T R A C T
Published materials on the mosses of the Russian Far East are summarized. Nine hundred and thirty species of mosses were revealed, and a bibliography is provided for each taxon. The distribution of each taxon within 39 spatial units $(5 \times 5$ degrees latitude/longitude) is analyzed. The list for each square was regarded as the flora of minimal size involved in analysis. Analysis of interrelationships between each minimal flora has revealed seven floristic associations that correspond to the following territories: Beringian Chukotka, the continental part of Chukotka Autonomous District and continental part of Magadan Province, northern coast of the Sea of Okhotsk, Kamchatka and adjacent islands, Sakhalin and southern Kurils, Russian Manchuria, and the rest part of continental southern Russian Far East. Centers of moss species diversity are considered.

K e y w o r d s : Russian Far East, mosses, bryoflora, distribution patterns, diversity, conservation, phytogeography
\end{abstract}

\section{P E 3 Ю M E}

Писаренко О.Ю., Бакамин В.А. Закономерности распространения разнообразия мхов и естественные агломераты мокальных моховых фмор на российском Аамьнем Востоке. Проведена ревизия опубликованных материалов по мхам российского Аальнего Востока; общий список включает 930 вилов. Приводится библиография. Составлена таблица распределения вилов по 39 вылелам территории размера $(5 \times 5$ граАусов широты/Аолготы). Сравнение списков вилов мхов по «квадратам» выявило 7 фмористических агломераций, соответствующих следующим территориям: Берингийская Чукотка, континентальные части Чукотки и МагаАанской области, северное побережье Охотского моря, Камчатка и прилегающие острова, Сахалин и южные Курилы, южное Приморье, остальная часть юга Аальнего Востока. Рассмотрены центры видового разнообразия мхов. Выявлено, что 6 основных центров охватывают более 4/5 видового состава фморы мхов российского Аальнего Востока.

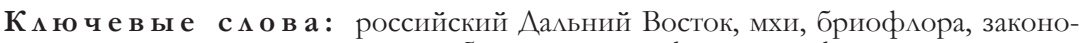
мерности распространения, разнообразие, охрана, фитогеография
The examination of spatial patterns of taxonomic diversity and richness is a necessary stage for the conservation and sustainable use of biological resources. Moss species diversity in non-tropical Eurasia is higher in oceanic regions, whereas inland territories have poorer moss floras, with highest diversity occurring in the mountainous areas with high amounts of rainfall (Ignatov 1993, 2001). The Russian Far East covers more than 3000000 square kilometers in latitudinal span from $72^{\circ} \mathrm{N}$ to $42^{\circ} 30^{\prime} \mathrm{N}$. Zonal communities in the area range from arctic tundra in the North to cool temperate forests in the South. The great variability in climate, landscapes and geology of the Russian Far East results in a taxonomically diverse flora, with many taxa occurring only here in the country. The Russian Far East houses ca. $80 \%$ of the bryophyte taxonomic diversity of Russia; more than a quarter of species of the Far Eastern moss flora do not occur in Russia outside of it.

This paper continues the investigation on bryophyte distribution patterns in the Russian Far East. We follow the previous work on liverworts and hornworts (Bakalin 2013) but deal with the moss portion of the biota. The aims of the present work are: 1) to summarize published moss data for the Russian Far East, to attribute the data on plots of the area according to grid cells $5 \times 5$ degrees, to evaluate the state of knowledge of moss flora of the plots; 2) to consider moss taxonomic diversity 'hot spots' in the Russian Far East; and 3) to estimate latitudinal ( $\sim$ zonal) patterns of the moss flora in the Russian Far East.

\section{MATERIAL AND METHODS}

This paper uses basically the same approaches for analysis of diversity distribution patterns as proposed for hepatics of the Russian Far East (Bakalin 2013). The studied area was divided into plots $5 \times 5$ degrees in latitude and longitude. These quasi-squares (further 'squares') are numbered with a general trend from northeast to south (Fig. 1). They vary in area from $112243 \mathrm{~km}^{2}$ (in latitudes $65-70^{\circ} \mathrm{N}$ ) to $208747 \mathrm{~km}^{2}$ (in latitudes $45-50^{\circ} \mathrm{N}$ ). Some of them are completely 'land' squares, whereas in some squares sea surface occupies more than $90 \%$ of the area. Then the distribution of each moss species recognized in the Russian Far East through the set of squares was reviewed. In the 


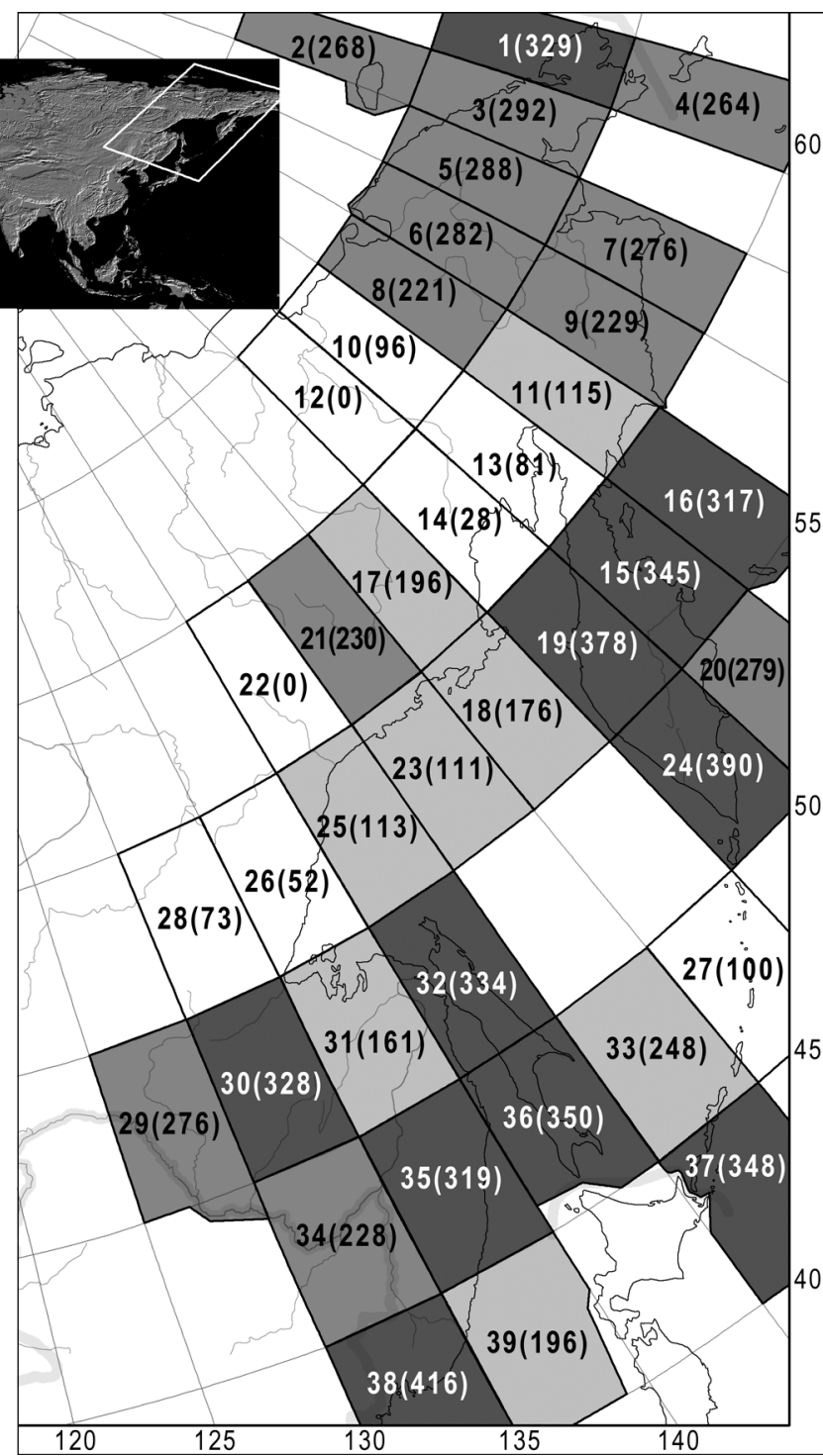

Figure 1 The subdivision of the territory into squares, their numeration and number of recorded moss species per square (in brackets)

case of comparatively small islands on a boundary of two squares moss data were ascribed as follows: Wrangel Island - square No. 2, Commander Islands - square No. 16, Iturup Island - square No. 33.

The most valuable procedure was to reveal the distribution of moss taxa through the Russian Far East - the information was then placed in the data matrix used for subsequent analyses. The matrix represents the table with the indication of the distribution of each revealed taxon within 38 squares (presence -1 , absence -0 ). The database was based on published papers, with the most valuable placed into Table 1 . Along with regional lists and notes on new records, the data from recent taxonomic revisions have been taken into account. The main revisions used are following: Brachytheciaceae (Ignatov et al. 2015, Ignatov \& Milutina 2007ab, 2010, Huttunen et al. 2015), Polytrichaceae (Ivanova et al. 2005, 2014, 2015, Ivanova \& Ignatov 2007); Anacamptodon (Czernyadjeva 2007), Anoectangium (Ignatova 2009), Aongstroemia (Drugova 2010), Bryoerythrophyllum (Fedosov \& Ignatova 2008), Coscinodon (Ignatova et al.
2008), Dichelyma (Czernyadjeva \& Ignatova 2013), Dicranum (Ignatova \& Fedosov 2008, Tubanova et al. 2010, Tubanova \& Ignatova 2011), Didymodon (Afonina \& Ignatova 2007a, Afonina et al. 2010), Encalypta (Fedosov 2012a, 2012b, 2013), Grimmia (Ignatova \& Munoz, 2004, Ignatova et al. 2016), Hygrohypnum (Czernyadjeva 2004), Leptopterigynandrum (Ignatov et al. 2012), Lindbergia (Ignatov et al. 2010), Neckera (Ignatov et al. 2009), Orthotrichum (Fedosov \& Ignatova 2011), Philonotis (Koponen et al. 2012), Pohlia (Czernyadjeva 1999), Pylaisiadelpha (Afonina et al. 2007), Schistidium (Blom et al. 2006, Ignatova et al. 2010, Ignatova et al. 2016), Scouleria (Ignatova et al. 2015), Sphagnum (Maksimov 2007, Maksimov \& Ignatova 2008, Lapshina \& Maksimov 2014, Flatberg et al. 2016, Maksimov et al. 2016), Stereodon (Afonina 2004a, Afonina \& Ignatova 2007b), Syntrichia (Afonina et al. 2014), Thamnobryum (Ignatova \& Ignatov 2011).

All data were collected and sorted using the IBIS 6.2 software (Zverev 2007). The resulting table is available online in the electronic version of the paper (online appendix). Nomenclature of mosses follows to Ignatov et al. (2006) with some recent updates (www.arctoa.ru/Flora/).

The number of known species was evaluated for each square. The squares were sorted from not studied to wellstudied and then the diversity 'hot spots' were found in the course of speculative analysis of the distribution of the taxa within the most taxonomically rich squares.

Species lists of all squares were regarded as the minimal flora involved in the analysis. The species lists for each 'minimal flora' were compared using cluster and detrended correspondence analysis to find interrelationships between minimal floras and to reveal natural flora associations. The dendrogram and ordination diagram were obtained with PAST 2.14 (Hammer et al. 2001).

\section{RESULTS AND DISCUSSION}

The compiled database (online appendix) includes 930 species distributed through 38 squares. The numbers of recorded species for each square are shown in Fig. 1 and 2.

The number of known species reflects 'exhaustiveness' in bryological studies for each square and varies drastically: from 0 to 416 species. On the other hand, the general regularities of taxonomic diversity distribution are sometimes obvious even from this undoubtedly incomplete matrix. For example, in humid regions of Northern Palearctic there is a general tendency of increasing species number in regional moss floras from North to South and in latitude range $80^{\circ} \mathrm{N}-40^{\circ} \mathrm{N}$ the number may increase by more than two times (Ignatov 2001). Previously we recognized 300-400 recorded taxa per unit as a confirmation of more or less comprehensive bryofloristic study there. Within 'northern' squares the same number could be somewhat less and reaches about 200-300 species per unit. A revealed taxonomic diversity of less than 100 species per square shows that the unit is undoubtedly poorly studied. These poorly studied squares are at the junction of Chukotskij Autonomous District, Magadan Province and Kamchatka Territory (Fig. 1, squares 10, 12, 13, 14), north of Khabarovsk Territory and Amur Province (Fig. 1, squares 22, 26, 28). The listed squares were excluded from subsequent analyses. A 
Table 1. Main sources of bryoflora information by sectors of the territory

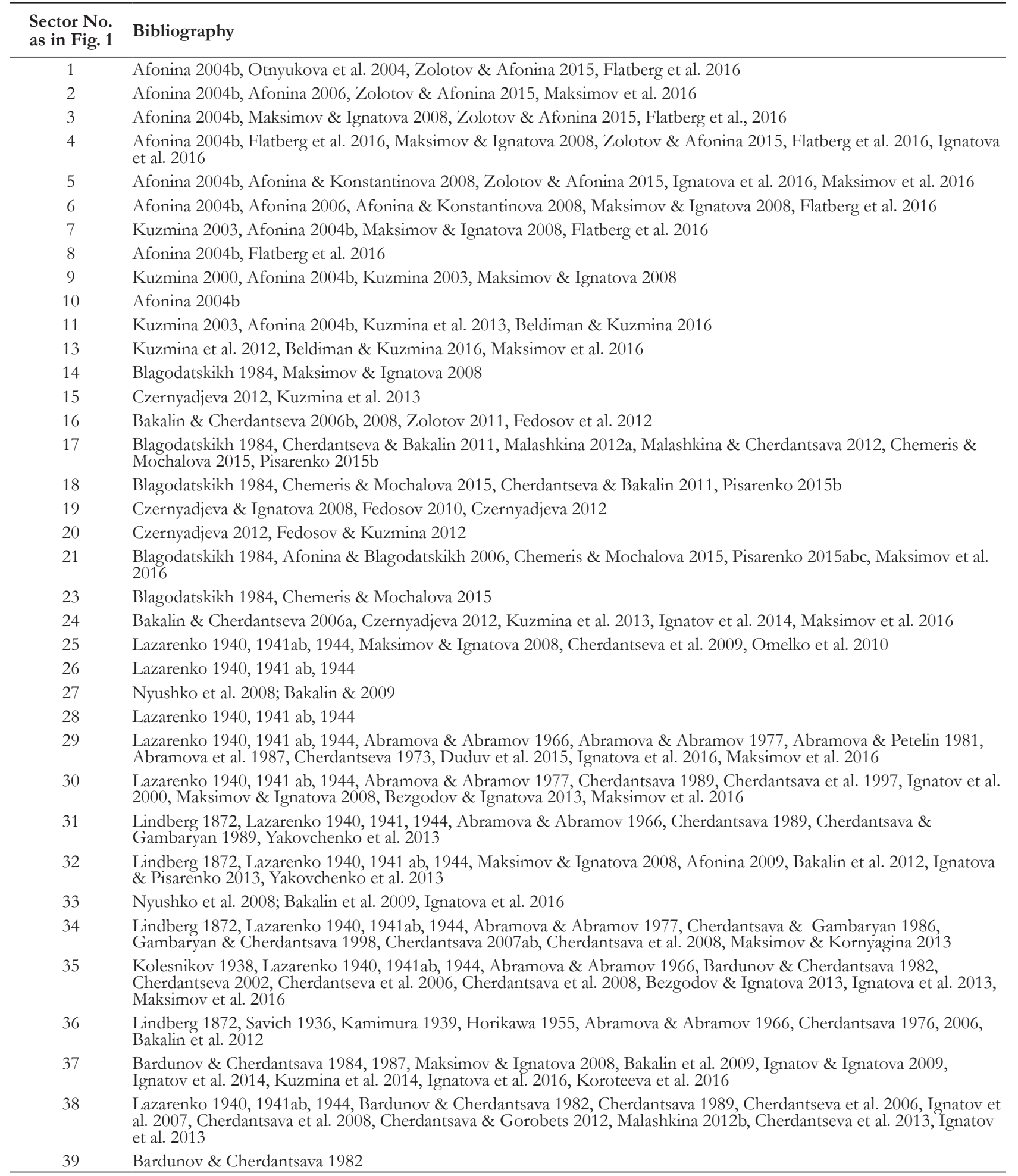

value of a little bit more than 100 species per unit (Fig. 1, squares $11,23,25,27)$ mean the square is poorly studied, but we included it in the analyses.

In total, 31 squares were considered in the analysis; 24 of them are properly studied (Fig. 1, dark and medium gray fill) and for the seven remaining squares moss diversity data are not as rich, though certainly not exhaustively known (Fig. 1, light gray fill).

\section{'Hotspots' of moss diversity in the Russian Far East}

As well as in the case of hepatics (Bakalin 2013), there were no direct relationships between the number of recorded species and the land area in the square, i.e. squares 'occupied' mostly by the sea are not distinctly poorer that completely 'land' squares. The most taxonomically rich squares are: squares 38 (416 species, south of Primorsky Territory), 24, 19, 15 (390, 378, 345 species, all in Kamchatka Penin- 


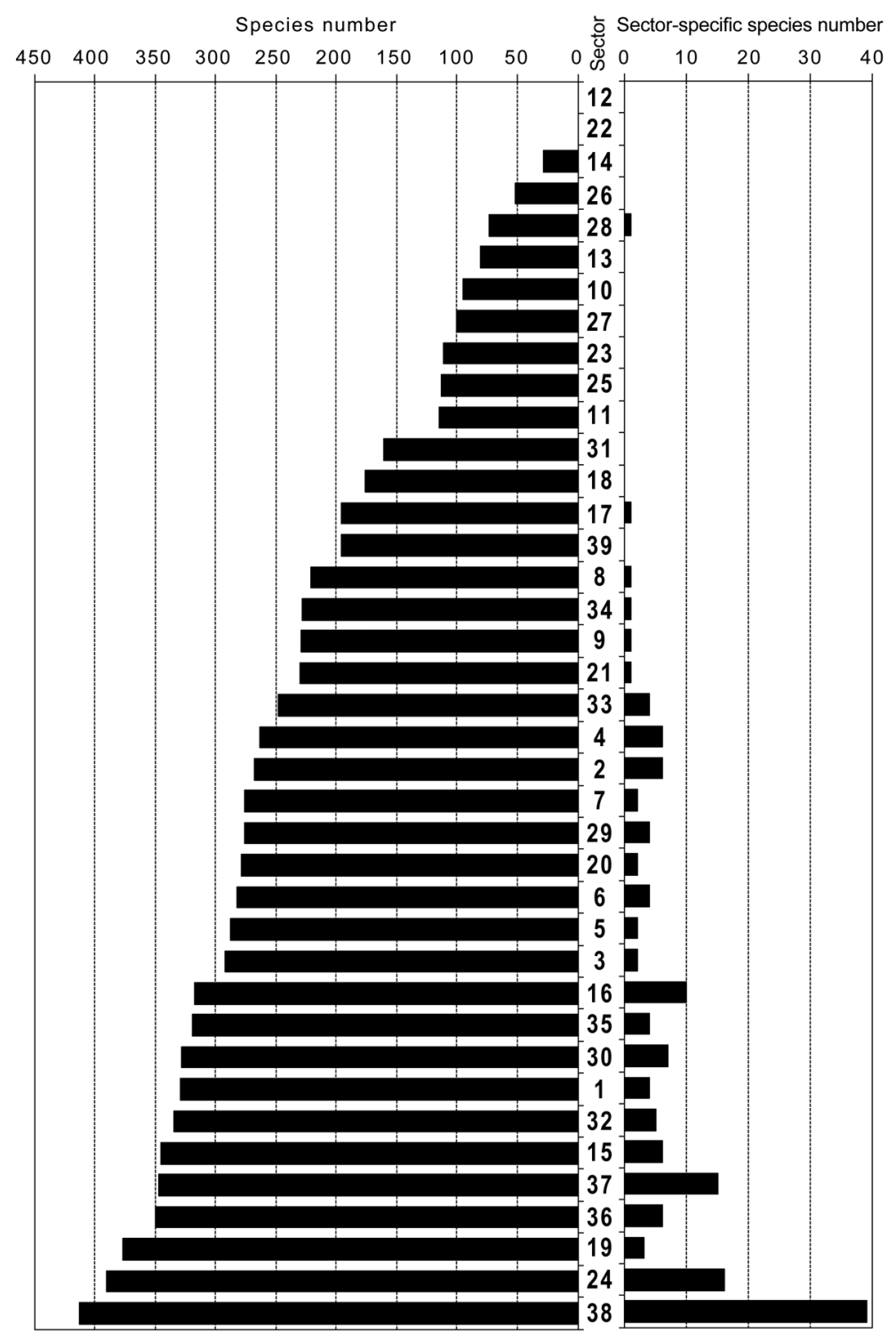

Figure 2 Number of recorded species (left) and number of square-specific species (right) by squares

sula), 37 (348 species, South Kurils), 32 and 36 (334 and 350 species, both mostly in Sakhalin Island), 30 (328 species, east of Amur Province), 1 (329 species, the east of Chukotka) and 16 (317 species, Commanders).

In fact the high diversity of the square is associated with different causes, which are considered below:

1. The taxonomic diversity in square 38 is mostly concentrated in the southern part of Sikhote-Alin and its southern spoors, where 351 moss species are recorded (Bardunov \& Cherdantseva 1982; unpublished data), comprising $83 \%$ of the total number of moss taxa of Primorsky Territory.

2. Kamchatka Peninsula is one of the best bryologically investigated areas in Russia and counts over 550 recorded species (Czernyadjeva 2005, 2012, Czernyadjeva \& Ignatova 2008, Fedosov 2010, Fedosov \& Kuzmina 2012, Fedosov \& Ignatova 2012). Most of the diversity is housed in the central part of the Sredinnyj Mt. Range where 357 (65\%) of species are recorded. The best studied (and apparently richest) territory on the ridge is Bystrinsky Nature Park where 306 moss species have been recorded.

3. South Kurils is also an exceedingly taxonomically rich area, where 416 species have been recorded within area less than $8000 \mathrm{~km}^{2}$. The latter number is not the final, and according to the recent studies the total number of taxa known in the area is close to 450 (unpublished data of Fedosov and Pisarenko).

4. Sakhalin Island has recently been well investigated (Bakalin et al. 2012, with several additions in Ignatova \& Pisarenko 2013, Ivanova et al. 2014, Lapshina \& Maksimov 2014). The highest diversity was observed in East Sakhalin Mountains, where 260 species (59\% of total island diversity) were recorded.

5. Bering Island is also one of the hot spots of taxonomic diversity of the Russian Far East. Although square 16 is in eleventh place in total ranging, the taxonomic diversity here is concentrated in the area less than 1/100 of the total square area; 312 taxa are recorded for the island.

6. Beringian Chukotka is characterized by high taxonomic diversity (391 species, Afonina 2004), with the most records coming from coastal areas.

The diversity centers are situated in approximately the same regions as those found in hepatics (Bakalin 2013). It should be noted however that these territories are among the best-studied areas in the Russian Far East. It seems in this case we have the complex process where the expectations of high diversity from researchers meet high taxonomic diversity in reality.

The six taxonomic diversity centers, as revealed above, include 778 taxa that comprise $83.7 \%$ of the total diversity in the Russian Far East. Only one of them (Bering Island) belongs to a strictly protected area (Komandorsky Strict Nature Reserve), although the protection of the moss flora in other areas is also highly realized.

\section{Spatial differentiation of the moss floras in the Russian Far East}

Initially we were inclined to think the affinity between taxonomic compositions of various squares in the Russian Far East should be relatively high. This estimation was based on two facts: 1) the widely known ability of moss taxa to find 'micro-niches' in landscapes whose macro-climatic conditions may not be favorable to survival and 2) mostly mountainous relief of the area, which provides a wide range of local climatic conditions and thus the appropriate environments for arctic-alpine and oroboreal taxa, e.g., in the cool temperate zone. Surprisingly, the analysis showed that similarity is relatively low.

Two squares with no information on mosses were eliminated from the analysis. The remaining 37 squares only have 
Table 2. Moss diversity and unique species of 39 designated squares and 7 square clusters of the Russian Far East

\begin{tabular}{|c|c|}
\hline $\begin{array}{l}\text { No. of } \\
\text { square }\end{array}$ & Unique species per sector; number and list \\
\hline \multicolumn{2}{|c|}{ Beringian Chukotka \& Vrangel Island cluster } \\
\hline 1 & 4: Bryum axel-blyttii, Oreas martiana, Orthotrichum laevigatum, Seligeria oelandica \\
\hline 2 & $\begin{array}{l}\text { 6: Bryum nitidulum, Didymodon maximus, Pterygoneurum ovatum, Schistidium frisvollianum, } \\
\text { S. grandirete, Tomentypnum falcifolium }\end{array}$ \\
\hline 3 & 2: Drepanocladus latinervis, Schistidium venetum \\
\hline 4 & $\begin{array}{l}\text { 6: Amblyodon dealbatus, Didymodon leskeoides, Grimmia beringiensis, Plagiothecium undulatum, Poblia } \\
\text { torrentium, Sciuro-bypnum ornellanum }\end{array}$ \\
\hline
\end{tabular}

Rest of Chukotka \& Continental part of Magadan Province cluster

5 2: Pterygoneurum lamellatum, Warnstorfia procera

6 4: Poblia sphagnicola, P. vexans, Polytrichastrum papillatum, Schistidium flexipile

7 2: Orthotrichum pallens, Tayloria serrata

8 1: Meesia hexasticha

9 1: Pseudocalliergon angustifolium

110

17 1: Bryum longisetum

21 1: Poblia atropurpurea

Northern coast of the Okhotsk sea cluster

180

$\begin{array}{ll}23 & \mathbf{0} \\ 25 & \mathbf{0}\end{array}$

Kamchatka Peninsula, Bering \& Paramushir Islands cluster

15 6: Arctoa anderssonii, Bryum kunzei, Didymodon gaochienii, Grimmia fuscolutea, Pylaisia curviramea, Sciuro-bypnum dovrense

16 10: Brachythecium frigidum, Bucklandiella macounii, Claopodium bolanderi, Didymodon vinealis, Drepanocladus sordidus, Lescuraea baileyi, Lescuraea saviana, Rhytidiadelphus loreus, Sphagnum tescorum, Ulota phyllantha

19 3: Didymodon maschalogenus, Encalypta microstoma, Tayloria splachnoides

20 2: Poblia viridis, Tetrodontium brownianum

24 16: Brachydontium olympicum, B. trichodes, Bryum alpinum, B. mayrii, B. mueblenbeckii, B. violaceum, Campylopus atrovirens, C. umbellatus, Homalothecium lutescens, Loeskeobryum brevirostre, Niphotrichum barbuliodes, Ochyraea smithii, Plagiothecium platyphyllum, Sphagnum annulatum, Splachnum melanocaulon, Timmiella corniculata

\section{Sakhalin \& Kuril Islands cluster}

32 5: Amblystegium minutissimum, Didymodon fallax, Fissidens neomagofukui, Orthotrichum furcatum, Platydictya fauriei

36 6: Didymodon perobtusus, Palustriella decipiens, Rhynchostegium rotundifolium, Schistidium flaccidum, S. sinensiapocarpum, Sphagnum pungifolium

37 15: Barbula indica var. kurilensis, Brotherella henonii, Campyliadelphus elodes, Campylium squarrosulum, Conardia compacta, Dicranum japonicum, D. setifolium, Didymodon tophaceus, Ditrichum rbynchostegium, Glossadelphus ogatae, Grimmia atrata, Hypnum fuijyamae, Plagiobryum bultenii, Stereodon dieckei, Thuidium glaucinoides

33 4: Dichelyma japonicum, Fissidens nobilis, Philonotis marchica, Sphagnum subtile

270

Amur Province, south of Khabarovsk Territory \& north of Primorsky Territory cluster

29 4: Anomodon viticulosus, Entosthodon pulchellus, Fontinalis dalecarlica, Schistidium austrosibiricum

30 7: Actinothuidium hookeri, Cynodontium fallax, Dicranodontium asperulum, Grimmia unicolor, 310 Hedwigia stellata, Lyellia crispa, Sphagnum auriculatum

35 4: Brachythecium dahuricum, Pylaisia steerei, Rhizomnium hattorii, Schistidium pruinosum

34 1: Glyphomitrium warburgii

390

\section{South Primorsky Territory cluster}

38 39: Anomodon abbreviatus, A. solovjovii, Archidium alternifolium, Brachythecium belminthcladum, Campylium radicale, Coscinodon pseudohartzii, Dicranoloma cylindrothecium, Didymodon cordatus, Entodon giraldii, E. rufescens, E. sullivantii, Entosthodon muhlenbergii, Ephemerum spinulosum, Fissidens hyalinus, Forsstroemia stricta, F. trichomitria, Haplobymenium longinerve, Homaliadelphus targionianus var. laevidentatus, Hyophila involuta, Lindbergia geniculata, Macromitrium bymenostomum, Meteorium buchananii, Miyabea fruticella, M. rotundifolia, Neckera goughiana, N. konoi, N. polyclada, Orthotrichum consobrinum, Physcomitrium eurystomum, Plagiothecium cordifolium, P. succulentum, Pylaisiadelpha tristoviridis, Rhizomnium parvulum, Schistidium elegantulum, Seligeria recurvata, Stereodon calcicola, Taxiphyllum alternans, Weissia planifolia, Weissia rutilans

19: Bryobrittonia longipes, Bryum calophyllum, B. mirabile, Bucklandiella afoninae, Campylium longicuspis, Didymodon jobansenii, D. subandreaeoides, Encalypta mutica, Funaria polaris, Niphotrichum elongatum Schistidium andreaeopsis, 9 . boreale, S. submuticum, Seligeria polaris sphagnum arcticum, S. olafii, Tayloria hornschuchii, Tortula laureri, Voitia byperborea

4: Hamatocaulis lapponicus, Orthotrichum pellucidum, Scouleria rschewinii, Tortula acaulon
18: Bucklandiella vulcanicola, Dicranum spurium, Didymodon brachyphyllus, D. bedysariformis, Grimmia anomala, G. triformis, Hygrohypnella bestii, Kiaeria falcata, Lescuraea secunda, Pleuridium subulatum, Poblia cardotii, P. obtusifolia, Sanionia orthothecioides, Schistidium dupretii, Sphagnum inexpectatum, Stereodon callichrous, Thuidium thermophilum, Tortula muralis

14: Brachythecium extremiorientale, Campylophyllum halleri, Dicranella curvipes, Dicranum hamulosum, Fissidens teysmannianus, Isothecium bakkodense, Mielichboferia japonica, Mnium orientale, Neckera borealis, Pseudotaxiphyllum pobliaecarpum, Pylaisia obtusa, Sciuro-bypnum brotheri, Thuidium tamariscinum, Ulota japonica

6: Brachythecium complanatum, Grimmia mueblenbeckii, Orthotrichum iwatsukii, O. striatum, Physcomitrium sphaericum, Poblia lutescens 
three species in common (Aulacomnium palustre, Hylocomium splendens, Sanionia uncinata). Further, if we were to eliminate from analysis six more squares where less than 100 species per square are known, only three more common species (Ceratodon purpureus, Pogonatum dentatum, Polytrichum juniperinum) will be added. This fact suggests drastic regional differentiation of the moss flora in the Russian Far East.

The opposite situation is the specificity of each square. About $1 / 6$ of the species list (152 taxa) are known from only one square (Fig. 2, Table 2). The richest square flora bears the highest numbers of specific taxa. The number of specific taxa varies from 0 to 16 , with the prominent exclusion of the very specific 'Manchurian' square (No. 38) that houses 40 species.

To find some statistically reliable relationships in the flora we have compared moss lists of all squares using detrended correspondence analysis (DCA) and cluster analysis (Ward's Method) (Figs. 3, 4). Both methods showed similar regularities (although 9 groups are separable by DCA, but 7 by cluster analysis). It is possible to recognize the following 'natural' groups according to moss flora similarity (cf. also Table 2):

- Beringian Chukotka \& Wrangel Island - 37 specific taxa (squares 1-4, Fig. 4-A; Fig. 5-I);

- continental part of Chukotka Autonomous District and continental part of Magadan Province - 16 specific taxa (squares 5-9, 11, 17, 21, Fig. 4-B, C; Fig. 5-II); - northern coast of the Okhotsk Sea - 0 specific taxa (squares 18, 23, 25, Fig. 4-D; Fig.5-III);

- Kamchatka Peninsula, Commanders and North Kurils - 55 specific taxa (squares 15, 16, 19, 20, 24, Fig. 4-E; Fig. 5-IV);

- Sakhalin and Kuril Islands (excluding North Kurils) - 44 specific taxa (squares $32,36,33,37$, Fig. 4-F, G; Fig. 5-V);

- Amur Province, South part of Khabarovsk Territory and North of Primorsky Territory - 22 specific taxa (squares 29-31, 34-35, Fig. 4-H, Fig.5-VI);

- south of Primorsky Territory - 40 specific taxa (square 38, Fig. 4-J, Fig. 5-VII).
The similarity between the moss cumulative floras (as defined above) is somewhat higher than between the squares themselves, although still remains relatively low. The clusters are defined due to two groups of species: (1) species, common for all squares of the cluster which unites them, and (2) species, peculiar for the cluster which separates it from other clusters.

The groups of species causing the separation of the described units are reflected in Fig. 5. The figure shows in graphical form the distribution types of mosses in the Russian Far East: strips show types of species occurrence by the clusters, thickness of a stripe correlates with the number of species.

The symbols a, b, c, e, f, g, h, j (Fig. 5) correspond to the letter symbols of the clusters (Fig. 3); the lists of taxa specific for the clusters are in Table 2. In addition the following categories are introduced into the comparison: $n$ - taxa restricted to the northern half of the Russian Far East; $\mathrm{k}$ - taxa distributed everywhere with the exception of southern Primorye; 1 - everywhere except in the North (Wrangel Island, Chukotka \& Magadan Province); $\mathrm{m}$ - taxa restricted to the southern half of the Russian Far East; $z$ taxa common for all clusters; $\mathrm{x}$ - taxa that have an indefinite (impossible to formalize) distribution.

Only 87 species are known in all seven clusters (Fig 5 - z). Those are boreal to arcto-boreal circumpolar species and are widespread in the Holarctic: Abietinella abietina, $A u$ lacomnium palustre, Brachythecium salebrosum, Bryoerythrophyllum recurvirostrum, Calliergon cordifolium, Calliergonella lindbergii, Ceratodon purpureus, Climacium dendroides, Dicranum majus, Distichium capillaceum, Eurbynchiastrum pulchellum, Hylocomium splendens, Hypnum cupressiforme, Mnium thomsonii, Niphotrichum canescens, Oncophorus wablenbergii, Plagiomnium ellipticum, Polytrichum piliferum, P. strictum, Rhizomnium magnifolium, Sanionia uncinata, Sphagnum capillifolium, S. girgensohnii, Straminergon stramineum, Thuidium assimile, Warnstorfia exannulata, etc.

If we were to eliminate cluster D (northern coast of the Okhotsk Sea) from the analysis, the number of the common species among the remaining clusters increases to 35 (Fig. 5 - w: Bryum amblyodon, Anomobryum concinnatum, Brachythecium

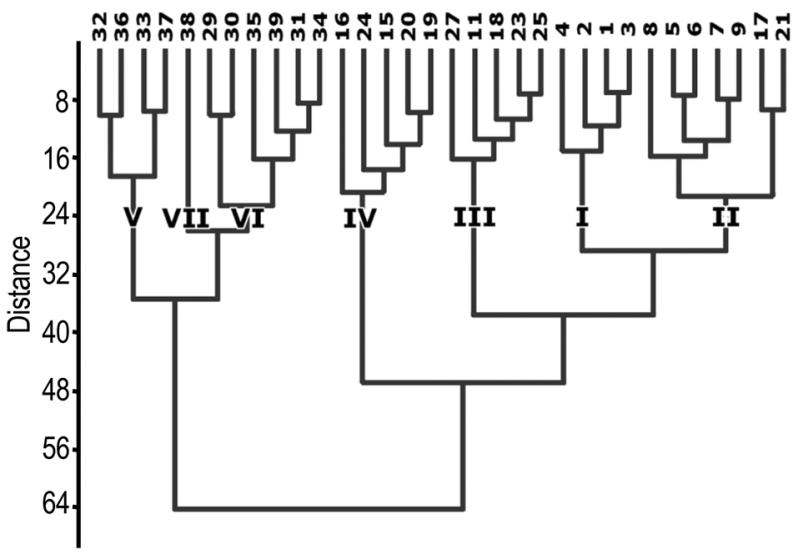

Figure 4 Dendrogram of similarity of moss lists of the squares of the Russian Far East (Ward's method). (Squares with less than 100 species recorded are not included)
Figure 3 DCA ordination diagram of moss lists of the squares of the Russian Far East. The squares (numbered) group into some clusters (dotted lines with letters). (Squares with less than 100 species recorded are not included) 
erythrorrhizon, Breidleria pratensis, Bryum cyclophyllum, B. elegans, B. pseudotriquetrum, Bucklandiella microcarpa, Cnestrum schistii, Dichodontium pellucidum, Dicranella schreberiana, Dicranum fuscescens, Drepanocladus polygamus, Encalypta ciliata, Entodon concinnus, Fissidens bryoides, F. osmundoides, Grimmia longirostris, Gymnostomum aeruginosum, Hamatocaulis vernicosus, Hymenostylium recurvirostrum, Neckera pennata, Ochyraea duriuscula, Oxystegus tenuirostris, Plagiomnium medium, Plagiopus oederianus, Platydictya jungermannioides, Polytrichum densifolium, Schistidium papillosum, Sciuro-hypnum plumosum, S. starkei, Sphagnum balticum, Stereodon bambergeri, S. subimponens, Trichostomum crispulum). The lack of a given species in the area is possible to explain by an insufficient knowledge of local floras composing that cluster, but also by the peculiar and uniform hemiarctic climate and acidic rock dominance.

Naturally the distribution of many of taxa in the Far East is limited by its northern part. The latter group includes species specific for squares $1-9,11,17,21$ and corresponding clusters, there is the set of taxa that are not registered further south of Chukotka \& Magadan Province (Fig. 5 - n: Aulacomnium acuminatum, Cinclidium arcticum, Didymodon acutus, Distichium hagenï, Drepanocladus arcticus, Encalypta longicollis, Grimmia anodon, Leptopterigynandrum austro-alpinum, Mnium blyttii, Molendoa tenuinervis, Ochyraea mollis, Plagiothecium svalbardense, Pseudocalliergon brevifolium, Schistidium holmenianum, Splachnum vasculosum, Stegonia latifolia, S. pilifera, Tetraplodon pallidus, T. paradoxus, Timmia sibirica, Warnstorfia pseudosarmentosa, etc.). Many of them have mainly arctic and hemiarctic areas of distribution.

On the contrary, the specificity of southern squares results from taxa of subtropical, or nearly so distribution (Entodon giraldii, Forsstroemia trichomitria, Homaliadelphus targionianus, Hyophila involuta, Macromitrium hymenostomum, Meteorium buchananii, Miyabea fruticella, $M$. rotundifolia, Taxiphyllum alternans, etc.; of. Bardunov et al. 2008). In addition, there are the series of temperate taxa that do not occur in the boreal zone and northward and, therefore, cause the negative specificity of the northern group of clusters. Most of them are characterized by East Asian distribution (Fig $6-\mathrm{m}$ : Anacamptodon latidens, Anomodon giraldii, A. thraustus, Bartramiopsis lescurii, Brachythecium auriculatum, B. buchananii, Claopodium pellucinerve, Codriophorus brevisetus, Dicranum hakkodense, D. pacificum, Echinophyllum sachalinense, Eurhynchiadelphus eustegius, Glyphomitrium humillimum, Leucodon pendulus, Okamuraea hakoniensis, Plagiomnium acutum, P. vesicatum, Pleuroziopsis ruthenica, Pogonatum contortum, P. japonicum, Pylaisiadelpha tenuirostris, Raviella fujisana, Rhizomnium striatulum, Rhytidiadelphus japonicus, Rigodiadelphus robustus, Sciuro-hypnum uncinifolium, Tetraphis geniculata, Trachycystis flagellaris, etc.).

Negative specificity is largest for the most southern square (and the same cluster) (Fig 5 - k: Bartramia ithyphylla, Blindia acuta, Brachythecium cirrosum, Bryum weigelii, Buxbaumia aphylla, Calliergon richardsonii, Dicranella cerviculata, D. subulata, Dicranum elongatum, D. groenlandicum, Grimmia reflexidens, Helodium blandowii, Hygrohypnella polare, Hymenoloma crispulum, Isopterygiopsis pulchella, Leptobryum pyriforme, Loeskypnum badium, Myurella julacea, Niphotrichum ericoides, Oligotrichum hercynicum, Paludella squarrosa, Poblia andrewsii, P. crudoides, P. wablenbergii, Polytrichastrum sexangulare, Polytrichum jensenii, Pseudobryum cin-

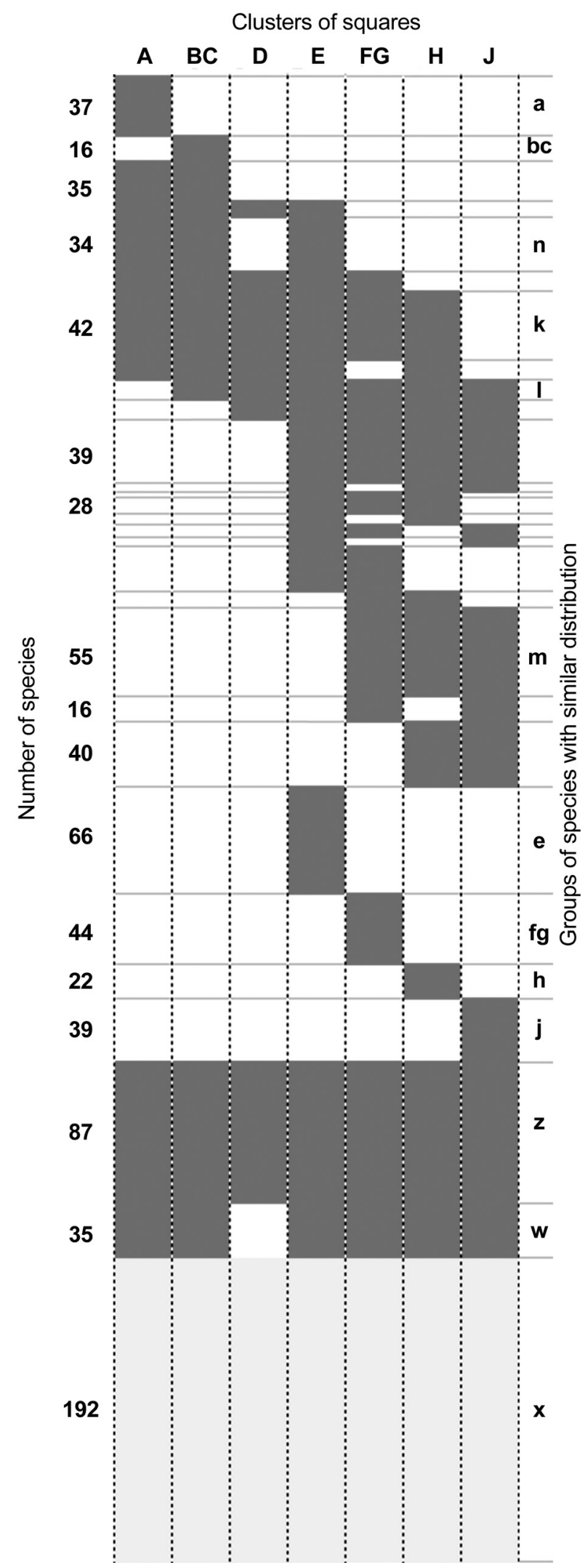

Figure 5 Graphical image of the table of moss species occurrence by clusters, which is sorted by peculiarity of species distribution. Capital letters mark clusters of squares according to Fig. 3. Gray strips show types of species occurrence by the clusters; thickness of a stripe correlates with the number of species; the numbers are given at left. Lowercase letters at right are groups of species with similar distribution by the clusters discussed in the text 
clidioides, Pseudoleskeella nervosa, Rhizomnium pseudopunctatum, Scorpidium revolvens, Sphagnum compactum, S. lindbergii, S. riparium, S. russowii, S. teres, S. warnstorfii, Splachnum rubrum, Tomentypnum nitens, Tortula hoppeana, Warnstorfia fluitans, etc.). Many of them have mainly arctic-alpine distributions and are quite common northward. The relatively low elevations of the mountains in the southern flank of the continental Russian Far East does not permit them to survive.

The peculiar position of Kamchatka and adjacent islands should be noted. The cluster is the southern limit for many 'northern' species and at the same time it is the northern limit for numerous 'southern' taxa (Fig. 5). This character places Kamchatka 'between' boreal and Hemiarctic biomes. The latter circumstance, along with several species of the disjunctive distribution, results in outstanding taxonomical richness of the region.

Despite the difference in the approaches and used methods, the general traits of the subdivision of the Russian Far East according to moss flora similarity are the same as the regionalization developed for hepatics (Bakalin 2010). The Beringian and continental North-East Asia regions are well separated both for mosses and hepatics. The North Okhotsk region is not separated in hepatic flora analysis, and that could be a result of almost a complete lack of information on the hepatic flora in the southern portion of Magadan Province some years ago (the main researches on Magadan Province hepatics were carried out after 2010). Most parts of Kamchatka and adjacent islands are also separated both in mosses and hepatics. The same for the Manchurian part of the southern Far East. The continental part of the boreal Far East is also well defined in the hepatic analysis (although being divided there into two units, related to mostly boreal and mostly hemiboreal formations of the flora). At the same time relatively strong differences were observed in moss and hepatic regionalization of the 'insular' part of the southern Far East. For example, the hepatic flora of the southern Kurils is rather noticeably different from that of Sakhalin Island, whereas the moss floras of both the South Kurils and Sakhalin are rather similar. Whether it reflects more 'moisture-depending' nature of hepatics in comparison with mosses, or results from other reasons, cannot be evidently identified here.

\section{CONCLUSIONS}

1. The Russian Far East moss flora has outstanding value in Russia in the terms of environmental research and conservation purposes. Nine hundred and thirty taxa were recorded for the territory as of September 2016.

2. The maximal taxonomic diversity of the mosses within the Russian Far East is observed in the Bystrinsky Nature Park in the Kamchatka Peninsula, East-Sakhalin Mountains, Iturup Island in the Kurils, Bering Island in the Commanders, eastern coast of Beringian Chukotka and southern flank of Sikhote-Alin Range. These areas are among the most exhaustively studied bryologically in respect to the territories in the Russian Far East. In total 778 species were recorded in these 'hot spots' for taxonomic diversity that comprises $83.7 \%$ of the total flora of the land. Among the localities listed, only one (Bering Island) is under protection by Federal law, whereas the conservation of bryophytes in other 'hot spots' should be among the crucial issues needed in proper management.

3. Seven territorial units are distinguishable according to moss flora similarity: Beringian Chukotka, continental part of Northeast Asia, northern coast of the Sea of Okhotsk, Kamchatka and adjacent islands, Sakhalin and southern $\mathrm{Ku}-$ rils, Russian Manchuria and the rest of continental South Far East. Noticeably, this subdivision is quite similar to that developed for hepatics in the area treated.

\section{ACKNOWLEDGEMENTS}

The work was prepared in scopes of program of the Federal agency for scientific organizations on support of biocollections for CSBG SB RAS and BGI FEB RAS and partially supported by the Russian Foundation for Basic Researches (grant 15-34-20101). Authors are deeply indebted to Dr. W.R. Buck (NY) for linguistic editing the manuscript.

\section{LITERATURE CITED}

Abramova, A.L. \& I.I. Abramov 1966. Rare moss species of Siberia and the Far East. Novosti Sistematiki Nirshih Rastenii 3:302-315 (in Russian). [Абрамова А.А., Абрамов И.И. 1966. Редкие виды мхов Сибири и Аальнего Востока. // Новости систематики низших растений. T. 3. C. 302-315].

Abramova, A.L. \& I.I. Abramov 1977. To the bryoflora of the Far East. Novosti Sistematiki Nizshib Rastenii 14:212219 (in Russian). [Абрамова А.А., Абрамов И.И. 1977. К бриофморе Аацьнего Востока / / Новости систематики низших растений. Т. 14. С. 212-219].

Abramova, A.L. \& I.I. Abramov 1978. On the species of the family Thuidiaceae in the USSR. Novosti Sistematiki Nizshib Rastenii 15:208-211 (in Russian). [Абрамова A.А., Абрамов И.И. 1978. О вилах семейства Тhuidiaceae в СССР // Новости систематики низших растений. T. 15. C. 208-211].

Abramova, A.L. \& I.I. Abramov 1981. To understanding of some moss species of the Soviet Far East. Novosti Sistematiki Nizshib Rastenii 18:153-178 (in Russian with English summary). [Абрамова А.А., Абрамов И.И. 1981. К пониманию некоторых Аальневосточных видов мхов СССР // Новости систематики низших растений. T. 18. C. 153-178].

Abramova, A.L., L.V. Bardunov, A.I. Gubanov, M.S. Ignatov, S.N. Korenyuk, V.S. Novikov, D.A. Petelin \& N.N. Stetsura 1987. Bryophytes and vascular plants of Zeya nature reserve. In: Flora and fauna of USSR nature reserves (I.A. Gubanov \& D.A. Petelin, eds.), vol. 1, 70 pp.,

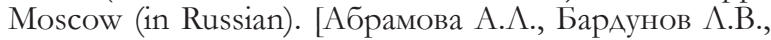
Губанов А.И., Игнатов М.С., Коренюк С.Н., Новиков В.С., Петелин А.А., Стецура Н.Н. 1987. Мохообразные и сосудистые растения Зейского заповеАника // ФАОра и фауна заповедников СССР / под реА. И.А. Губанова и А.А. Петелина. М. Вып. 1. 70 с.].

Abramova, A.L. \& D.A. Petelin 1981. Bryophytes. In: Flora and vegetation of Tukuringra ridge (Amur Province) (I.A. Gubanov, ed.), pp. 64-85, Moscow State University, Moscow (in Russian). [Абрамова А.А., Петелин А.А. 1981. Мохообразные // ФАора и растительность хребта Тукурингра (Амурская об̆ласть) / под реА. И.А. Губанова. М.: ИзА-во МГУ. С. 64-85].

Afonina, O.M. 2004 a. Hypnum sect. Hamulosa (Musci, Hypnaceae) in Russia. Arctoa 13:9-28 (in Russian with English summary). [Афонина O.М. 2004. Виды Нурпит секции 
Hamulosa (Musci, Hypnaceae) в России // Arctoa. Вып. 13. C. 9-28].

Afonina, O.M. 2004 b. Mosses of Chukotka. St. Petersburg. 260 pp. (in Russian) [Афонина O.M. 2004. Конспект флоры мхов Чукотки. С.-Петербург. 260 с.].

Afonina, O.M. 2006. New moss records from Chukotskij Autonomous District. 1. Arctoa 15:270.

Afonina, O.M. 2009. New moss records from Khabarovsk Territory. 2. Arctoa 18:279.

Afonina, O.M. \& L.S. Blagodatskikh 2006. New moss records from Magadan Province. 1. Arctoa 15:268.

Afonina, O.M., V.Ya. Cherdantseva, E.A. Ignatova \& M.S. Ignatov 2010. Symblepharis vaginata (Dicranaceae, Bryophyta), a new genus and species for the moss flora of Russia. Botanicheskii Zhurnal 95(12):1765-1770 (in Russian with English summary). [Афонина O.M., Черданцева В.Я., Игнатова Е.А., Игнатов М.С. 2010. Symblepharis vaginata (Dicranaceae, Bryophyta) - новый род и виА Аля фморы мхов России // Ботанический журнал. T. 95, № 12. C. 1765-1770].

Afonina, O.M., I.V. Czernyadjeva, E.A. Ignatova \& J. Kučera 2010. Five species of Didymodon (Pottiaceae, Bryophyta) new to Russia. Arctoa 19:51-62.

Afonina, O.M. \& E.A. Ignatova 2007 a. A new species of Didymodon (Pottiaceae, Musci) from Asian Russia. Arctoa 16:133-138.

Afonina, O.M. \& E.A. Ignatova 2007 b. East Asian species of Stereodon (Brid.) Mitt. (Pylaisiaceae, Musci) in Russia. Arctoa 16:7-20.

Afonina, O.M., E.A. Ignatova, V.E. Fedosov \& O.I. Kuznetsova 2014. Toward a new understanding of Syntrichia submontana (Pottiaceae, Bryophyta). Arctoa 23: 11-24.

Afonina, O.M. \& N.A. Konstantinova 2008. Bryophytes. In: Red Data Book of the Chukcchi Autonomus District (I.A. Chereschnev, ed.), pp. 125-165, Publishing house "Dikij Sever", Magadan (in Russian). [Афонина O.M., Константинова Н.А. 2008. Мохообразные // Красная книга Чукотского автономного округа. Том 2. Растения. / под реА. И.А. Черешнева. Магадан: ИзАательский дом «Аикий Север». С. 125-165].

Afonina, O.M., H. Tsubota \& E.A. Ignatova 2007. The genus Pylaisiadelpha (Pylaisiadelphaceae, Musci) in Russia Arctoa 16:127-132.

Bakalin, V.A. 2010. Distribution of bryophytes in the Russian Far East. Part. I. Hepatics. Izd-vo DVFU, Vladivostok, 175 pp.

Bakalin, V.A. 2013. Hepatic diversity patterns in the Russian Far East. Botanica Pacifica 2(1): 35-42.

Bakalin, V.A. \& V.Ya. Cherdantseva 2006 a. Bryophytes of northern Kuril Islands (north-west Pacific). Arctoa 15: 131-153.

Bakalin, V.A. \& V.Ya. Cherdantseva 2006 b. New materials to the knowledge of bryoflora of the Commander Islands. In: Biodiversity of plant cover of the Far North: inventory, monitoring, protection. All-Russian Scientific Abstracts. konf. Syktyvkar, 22-26 May 2006 (S.V. Degteva, ed.), pp. 4-6, Syktyvkar (in Russian). [Бакалин B.А., Черданцева B.Я. 2006. Новые материалы к познанию бриофлоры Командорских островов // Биоразнообразие растительного покрова Крайнего Севера: инвентаризация, мониторинг, охрана: Тезисы Всероссийской науч. конф.Сыктывкар, 22-26 мая 2006 г. / под реА. С.В. Аегтевой. Сыктывкар. С. 4-6].

Bakalin, V.A. \& V.Ya. Cherdantseva 2008. Bryophyte flora of Mednyj Island and bryogeography of the Aleutians (North Pacific). In: Biodiversity conservation of Kamchatka and surrounding sea. Reports of VIII scientific conf. November 27-28, 2007 (V.F. Bugaev, ed.), pp. 36-56, Petropavlovsk-Kamchatskii (in Russian). [Бакалин B.A., Черданцева В.Я. 2008. Бриофлора острова Медный и бриогеография Алеут (Северная Пацифика). // Сохранение биоразнообразия Камчатки и прилегающих морей. Аоклады VIII науч. конф. 27-28 ноября 2007 г. / под реА. В.Ф. Бугаева. Петропавцовск-Камчатский. С. 36-56].

Bakalin, V.A., V.Ya. Cherdantseva, M.S. Ignatov, E.A. Ignatova \& T.I. Nyushko 2009. Bryophyte flora of the South Kuril Islands (East Asia). Arctoa 18:69-114.

Bakalin, V.A., O.Yu. Pisarenko, V.Ya. Cherdantseva, P.V. Krestov, M.S. Ignatov \& E.A. Ignatova 2012. Bryophytes of Sakhalin. Izd-vo Morskogo gosuniversiteta, Vladivostok, 310 pp. (in Russian). [Бакалин В.А., Писаренко О.Ю., Черданцева В.Я., Крестов П.В., Игнатов М.С., Игнатова Е.А. 2012. Бриофлора Сахалина. Владивосток: ИзА-во Морского госуниверситета, 2012. 310 с.].

Bardunov, L.V. \& V.Ya. Cherdantseva 1978. Bryophytes. In: Flora and vegetation of Ussuri nature reserve (S.S. Kharkevich, ed.), pp. 127-148, Nauka, Moscow (in Russian). [Бардyнов А.В., Черданцева В.Я. 1978. Мохообразные // ФАора и растительность Уссурийского заповедника / под ред. С.С. Харкевича. М.: Наука. С. 127-148].

Bardunov, L.V. \& V.Ya.Cherdantseva 1980. Subtropical element in moss flora of Southern Primorye. Botanicheskii Zhurnal 65(12):1747-1758 (in Russian with English summary). [Бардунов А.В., Черданцева В.Я. 1980. Субттропический элемент во фморе мхов Южного Приморья // Ботанический журнал. Т. 65. № 12. С. 1747-1758].

Bardunov, L.V. \& V.Ya.Cherdantseva 1982. Mosses of the south of Primorskij Province. Nauka, Novosibirsk. 208 pp. (in Russian) [Бардунов А.В., Черданцева В.Я. 1982. Аистостебельные мхи Южного Приморья. Новосибирск: Наука. 208 с.].

Bardunov, L.V. \& V.Ya.Cherdantseva 1984. Materials on the moss flora of the South Kuril Islands. In: Sistematico-floristic studies of spore plants of the Far East (V.Ya. Cherdantseva, ed.), pp. 34-53, Vladivostok (in Russian). [Бардунов А.В., Черданцева В.Я. 1984. Материалы по фморе кистостебельных мхов Южных Курильских островов // Систематико-флористические исследования споровых растений Аальнего Востока / под реА. В.Я. ЧерАанцевой. ВАадивосток. С. 34-53].

Bardunov, L.V. \& V.Ya. Cherdantseva 1987. On moss flora of the southern Kuril islands. Botanicheskii Zhurnal 72(5):664-668 (in Russian with English summary). [БарАунов А.В., Черданцева В.Я. 1987. К флоре мхов южных Курильских островов // Ботанический журнал. T. 72, № 5. C. 664-668].

Bardunov, L.V. \& V.Ya. Cherdantseva 2006. Bryophytes. In: Flora, vegetation and mycobiota of the nature reserve "Ussuryjsky" (L.N. Vasilyeva, ed.), pp. 51-78, Dal'nauka, Vladivostok (in Russian). [Бардунов А.В., Черданцева В.Я. 2006. Мохообразные / / ФАора, растительность и микобиота заповедника "Уссурийский” / под реА. А.Н. Васильевой. ВАадивосток: Аальнаука. С.51-78].

Bardunov, L.V., S.K. Gambaryan \& V.Ya. Cherdantseva 2002. Bryophytes. In: Flora, mikobiota and vegetation of Lazo nature reserve, pp. 49-67, Russkiy ostrov, Vladivostok (in Russian). [Бардунов А.В., Гамбарян С.К., Черданцева В.Я. 2002. Мохообразные // ФАора, микобиота и растительность Аазовского заповедника. ВАадивосток, Русский остров. С. 49-67].

Bardunov L.V., V.Ya. Cherdantseva \& V.A. Bakalin 2008. Subtropical species in the bryophyte flora of the Russian Far East. Botanicheskii Zhurnal 93(2):263-270 (in Russian). 
[Бардунов А.В., Черданцева В.Я., Бакалин В.А. Субтропические виды в бриофлоре южной части российского Аальнего Востока / / Ботанический журнац. T. 93, №. 2. C. 263-270].

Beldiman, L.N. \& E.Yu. Kuzmina 2016. New moss records in Kamchatka Territory. 8. Arctoa 25:220-221 (in Russian). Бельдиман А.Н., Кузьмина Е.Ю. 2016. Новые находки мхов в Камчатском крае. 8. In: Sofronova E.V. (ed.). New bryophyte records. 6. // Arctoa Вып. 25. C. 220-221].

Blagodatskikh, L.S. 1984. Mosses of Kolyma Upland. Institut biologicheskih problem severa, Magadan, $47 \mathrm{pp}$. (in Russian). ББлагодатских А.С. 1984. Аистостебельные мхи Колымского нагорья. Магадан: Институт биологических проблем севера. 47 с.]. Available at: (http:// neisri.narod.ru/academnet/infocentr/f_f/flora/mhi/ mhi.htm)

Blom, H.H., E.A. Ignatova \& O.M. Afonina 2006. New records of Schistidium (Grimmiaceae, Musci) in Russia. Arctoa 15:187-194.

Brotherus, V.F 1914. Mosses (Andreaeales; Bryales part 1). In: Flora of Asiatic Russia. Vol. 4 (B.A. Fedchenko, ed.), pp. 1-78, Pereselencheskoye upravleniye, Petrograd (in Russian). [Бротерус В. Ф. 1914. Мхи (Andreaeales; Bryales часть 1) / / Фоора Азиатской России Вып. 4 / поА реА. Б.А. Федченко. ПетрограА, Переселенческое управление, 1914. С. 1-78].

Brotherus, V.F. 1918. Mosses (Bryales part 2). In: Flora of Asiatic Russia. Vol. 4 (B.A. Fedchenko, ed.), pp. 79-182, Pereselencheskoye upravleniye, Petrograd (in Russian). [Бротерус В.Ф. 1918. Мхи (Bryales часть 2) // ФАора Азиатской Россиию Вып. 4 / под реА. Б.А. ФеАченко. ПетрограА, Переселенческое управление, 1918. C. 79-182].

Brotherus, V.F. 1931. Mosses of Asian Russia (Bryales). Part 3. Trudy botanicheskogo sada Akademii Nauk SSSR 42(2):141-180 (in Russian). ББротерус В.Ф. 1931. Мхи Азиатской России (Bryales). Ч. 3 // Труды ботанического сала АН СССР. Т. 42, № 2. С. 141-180].

Brotherus, V.F., O.I. Kuzeneva \& N. Prokhorov 1916. List of mosses from Amur and Yakutsk Provinces. Trudy Botanicheskogo mureya Akademii nauk 16:1-71 (in Russian). [Бротерус В., Кузенева О., Прохоров Н. 1916. Список мхов из Амурской и Якутской областей / / Труды Ботанического музея Академии наук. Вып. 16. С. 1-71].

Cherdantseva, V.Ya. 1978. Materials to the bryoflora of Koryaksky National District. In: Algae, fungi and mosses of the Far East (Z.M. Azbukina, ed.), pp. 113-123, Vladivostok (in Russian). ЧЧерданцева В.Я. 1978. Материалы к бриофлоре Корякского национального округа // Водоросли, грибы и мхи Аальнего Востока /отв. реА. 3.М. Азбукина. ВАадивосток. С. 113-123].

Cherdantseva, V.Ya. 1989 a. The history of study of mosses of Soviet Far East. In: Problems of bryology in the Soviet Union (I.I. Abramov, ed.), pp. 207-213, Nauka, Leningrad (in Russian). [Черданцева В.Я. 1989. История изучения Аистостебельных мхов советского Аальнего Востока // Проблемы бриологии в СССР / поА реА. И.И. Абрамова. А.: Наука. С. 207-213].

Cherdantseva, V.Ya. 1989 b. Rare and interesting moss species in the Far East. Novosti Sistematiki Nizshikh Rastenii 26: 157-159 (in Russian with English summary). [ЧepАанцева В.Я. 1989. Редкие и интересные виды мхов Аальнего Востока // Новости систематики низших растений. Т. 26. С. 157-159].

Cherdantseva, V.Ya. 2001. Mosses of Sikhote-Alin' Bioshere Reserve (the Russian Far East, Primorsky Territory). Arctoa 11:229-244 (in Russian with English sum- mary). [Черданцева В.Я. 2001. Аистостебельные мхи Сихотэ-Алинского биосферного заповедника (Аальний Восток, Приморский край) // Arctoa. Вып. 11. C. 229-244].

Cherdantseva, V.Ya. 2007 a. Mosses. In: Flora, mycobiota and vegetation of Bastak nature reserve (T.A. Rubtsova, ed.), pp. 83-100, Dal'nauka, Vladivostok (in Russian). [ЧepАанцева В.Я. 2007. Аистостебельные мхи // ФАора, микобиота и растительность заповедника Бастак / отв. ред. Т.А. Рубцова. ВАадивосток: Аальнаука, 2007. C. 83-100].

Cherdantseva, V.Ya. 2007 b. Bryophytes. In: Red Data Book of Jewish Autonomous Province (S.D. Schlothauer, ed.), pp. 179189, Arta, Novosibirsk (in Russian). [Черданцева В.Я. 2007. Моховидные / / Красная книга Еврейской автономной области (реАкие и находящиеся поА угрозой исчезновения виАы растений и грибов / поА реА. С.А. ШАотгауэр. Новосибирск: Арта. С. 179-189].

Cherdantseva, V.Ya. \& V.A. Bakalin 2011. New moss records from Magadan province. 1. Arctoa 20:263.

Cherdantseva, V.Ya, V.A. Bakalin \& L.S. Yakovchenko 2013. Bryophyte flora and lichen biota of Litovka Mt. (Livadiysky Range, Russian Manchuria). V.L. Komarov Memorial Lectures 61:9-49 (in Russian with English summary). [Черданцева В.Я., Бакалин В.А., Яковченко А.С. 2013. Бриофлора и михенобиота горы Аитовка (АиваАийский хребет, российская Манчжурия) // Комаровские чтения. Т. 61. С. 9-49].

Cherdantseva, V.Ya. \& S.K. Gambaryan 1986. Bryophytes. In: Flora and vegetation of Bolshoi Khekhtsir nature reserve (A.B. Melnikov, ed.), pp. 79-101, Vladivostok (in Russian). [Черданцева В.Я., Гамбарян С.К. 1986. Мохообразные // ФАора и растительность Большехехцирского заповедника. / под ред. А.Б. Мельникова. ВАадивосток. C. 79-101].

Cherdantseva, V.Ya. \& S.K. Gambaryan 1989. Bryophytes. In: Fungi, lichens, algae and bryophytes of Komsomolsk reserve (Khabarovsk Territory) (Z.M. Azbukina \& V.Ya. Cherdantseva, eds.), pp. 109-135, Vladivostok (in Russian). [Черданцева В.Я., Гамбарян С.К. 1989. Мохообразные // Грибы, мишайники, водоросли и мохообразные Комсомольского заповедника (Хабаровский край) / под реА. 3.М. Азбукиной, В.Я. ЧерАанцевой. ВАаАивосток. С. 109-135].

Cherdantseva, V.Ya, S.K. Gambaryan \& V.A. Bakalin 2008. Bryophytes. In: Red Data Book of Primorsky Krai. Plants. Rare and endangered plant species (A.E. Kozhevnikov, ed.), pp. 381-437, Administration of Primorsky Krai, Vladivostok (in Russian). [Черданцева В.Я., Гамб̆арян С.К., Бакалин В.А. 2008. Мохообразные // Красная книга Приморского края. Растения. Редкие и находящиеся поА угрозой исчезновения виды растений / под реА. А.Е. Кожевникова. ВАадивосток: ААминистрация Приморского края. С. 381-437].

Cherdantseva, V.Ya., M.S. Ignatov \& E.A. Ignatova 2006. New moss records from Primorsky Territory. 1. Arctoa 15:263.

Cherdantseva, V.Ya, M.S. Ignatov \& V.A. Bakalin 2009. New moss records from Khabarovsk Territory. 1. Arctoa 18:279.

Cherdantseva, V.Ya., S.K. Gambaryan \& S.V. Osipov 1997. The bryophytes of the upper belts of the Amur-Uda interfluve Mountains (Far East). Botanicheskii Zhurnal 82(1): 54-62 (in Russian with English summary). [ЧepАанцева В.Я., Гамбарян С.К., Осипов С.В. 1997. Мохообразные верхних поясов гор Амуро-У Аского межАуречья (АаАьний Восток) // Ботанический журнал. T. 82, № 1. C. 54-62]. 
Cheremis, E.V. \& O.A. Mochalova 2015. New moss records in Magadan Province. 1. Arctoa 24:255-257 (in Russian). [Чемерис Е.В., Мочалова О.А. 2015. Новые находки мохообразных в Магаданской области. 1. In: Sofronova E.V. (ed.) New bryophyte records. 4. Arctoa. Вып. 24. P. 255-257].

Czernyadjeva, I.V. 1999. On the distribution of propaguliferous species of Poblia (Bryaceae, Musci) in Rusia. Arctoa 8:51-56.

Czernyadjeva, I.V. 2004. The genus Hygrobypnum (Amblystegiaceae, Musci) in Russia. Arctoa 12:25-58 (in Russian with English summary). [Чернядьева И.В. 2004. РоА Нygrohypnum (Amblystegiaceae, Musci) в России // Arctoa. Вып. 12. C. 25-58].

Czernyadjeva, I.V. 2007. The genus Anacamptodon (Amblystegiaceae, Bryophyta) in Russia and Transcaucasia. Arctoa 16:1-6.

Czernyadjeva, I.V. 2011. New moss records in Kamchatka Territory. 5. Arctoa 20:263-264 (in Russian). [Чернядьева И.В. 2011. Новые находки мхов в Камчатской обмасти. 5 // Arctoa. Вып. 20. С. 263-264].

Czernyadjeva, I.V. 2012. Mosses of Kamchatka Peninsula. Izdatel'stvo LETI, St. Petersburg, 459 pp. (in Russian). [Чернядьева И. В. 2012. Мхи полуострова Камчатка. Санкт-Петербург: ИзА-во “АЭТИ”. 459 с.].

Czernyadjeva, I.V. \& E.A. Ignatova 2013. Dichelyma (Fontinalaceae, Bryophyta) in Russia. Arctoa. 22:111-120.

Dokturovskij, V.S. 1912. To the moss flora of Amur Province. Izvestiva Imperatorskogo botanicheskogo sada 12(4):105120 (in Russian). [Аоктуровский В.С. 1912. К фморе мхов Амурской области / / Известия Императорского ботанического сада. Т. 12, № 4. С. 105-120].

Dudov, S.V., E.A. Ignatova \& V.E. Fedosov 2015. New moss records in Amur Province. 2. Arctoa 24:251-252 (in Russian). [Аудов С.В., Игнатова Е.А., Федосов В.Э. 2015. Новые находки мхов в Амурской области. 2. In: Sofronova E.V. (ed.) New bryophyte records. 4. Arctoa. Вып. 24. C. 251-252].

Drugova, T.R. 2010. The genus Aongstroemia in Russia. Arctoa 19:247-252.

Fedosov, V.E. 2010. New moss records from Kamchatskaya Province 5. Arctoa 19:279-280.

Fedosov, V.E. 2012 a. Encalypta sect. Rhabdotheca in Russia. Arctoa. 21: 101-112.

Fedosov, V.E. 2012 b. New moss records from Magadan Province. 2. In: New bryophyte records 1. (E.V. Sofronova, ed.). Arctoa 21:295.

Fedosov, V.E. 2013. The genus Encalypta Hedw. In: Moss flora of Russia. On-line version, 36 pp. (in Russian). [Федосов В.Э. 2013. Род Encalypta Hedw. - Энкалипта // ФАора мхов России. ЭАектронная пуб̆ликация. 36 с.]. Available at: http://arctoa.ru/Flora/taxonomy-ru/Encalypta-text-russian.pdf).

Fedosov, V.E., I.V. Czernyadjeva, E.A. Ignatova, O.I. Kuznetsova, A.V. Fedorova \& M.S. Ignatov 2016. On the Bryoxiphium norvegicum and B. japonicum (Bryoxiphiaceae, Bryopsida). Arctoa 25(1):52-68.

Fedosov, V.E. \& E.A. Ignatova 2008. The genus Bryoerythrophyllum (Pottiaceae, Bryophyta) in Russia. Arctoa 17:19-38.

Fedosov, V.E.\& E.A. Ignatova 2011. On Orthotrichum pellucidum and $O$. hallii (Orthotrichaceae, Bryophyta) in Russia. Arctoa 20:197-204.

Fedosov, V.E. \& E.A. Ignatova 2012. New moss records from Kamchatsky Territory. 6 (E.V. Sofronova, ed.). New bryophyte records. 1. Arctoa 21: 295-296.

Fedosov, V.E., E.A. Ignatova, M.S. Ignatov, A.I. Maksimov
\& V.I. Zolotov 2012. Moss flora of Bering Island (Commander Islands). Arctoa 21:113-164.

Fedosov, V.E. \& E.Yu. Kuzmina 2012. History and preliminary results of the Kronotsky reserve bryoflora studies. In: Proceedings of Kronotskii state natural biosphere reserve. Issue 2 (V. I. Mosolov, ed.), pp. 51-65, Kamchatpress, Petropavlovsk-Kamchatskii (in Russian). [Федосов В.Э., Кузьмина Е.Ю. 2012. История и предварительные результаты изучения бриофлоры Кроноцкого заповедника // Труды Кроноцкого государственного природного биосферного заповедника. Выпуск 2 / под реА. В.И. Мосолова. Петропавловск-Камчатский: Камчатпресс. С. 51-65].

Fedosov, V.E., E.Yu. Kuzmina \& V.Yu. Neshataeva 2015. Bryoflora of Geysers valley. In: Proceedings of Kronotskii state natural biosphere reserve. Issue 4 (E.G. Lobkov, ed.), pp. 52-73, Kamchatpress, Petropavlovsk-Kamchatskii (in Russian). [Федосов В.Э., Кузьмина Е.Ю., Нешатаева В.Ю. 2015. Бриофлора долины гейзеров // Труды Кроноцкого государственного природного биосферного заповедника. Вып. 4 / под ред. Е.Г. Аобкова. Петропавловск-Камчатский: Камчатпресс. С.52-73].

Flatberg, K.I., O.M. Afonina, Yu.S. Mamontov, V.E. Fedosov \& E.A. Ignatova 2016. On Sphagnum mirum and S. olafii (Sphagnaceae, Bryophyta) in Russia. Arctoa 25:96-101.

Flatberg K.I., E.A. Ignatova, O.M. Afonina 2016. New moss records from Chukotka Autonomous District. 2. In: Sofronova E.V. (ed.). New bryophyte records. 6. Arctoa 25:220.

Gambaryan, S.K. \& V.Ya. Cherdantseva 1998. Bryophytes. In: Flora and vegetation of Khingan nature reserve (L.N. Vasilieva, ed.), pp. 70-87, Dal'nauka, Vladivostok (in Russian). [Гамбарян С.К., Черданцева В.Я. 1998. Мохообразные // ФАора и растительность Хинганского заповедника (Амурская область) / под ред. А.Н. Васильевой. ВАадивосток: Аальнаука. С.70-87].

Gambaryan, S.K. \& V.Ya. Cherdantseva 2002. Bryophytes. In: The inventory of plants and fungi of the "Kedrovaya pad"'ture reserve, (R.I. Korkishko, ed.), pp. 21-30, Dal'nauka, Vladivostok (in Russian). [Гамб̄арян С.К., Черданцева В.Я. 2002. Мохообразные // КаАастр растений и грибов заповедника Кедровая падь / под реА. Р.И. Коркишко. ВАадивосток: Аальнаука, 2002. С.21-30].

Gorobets, K.V. 2004 Moss flora of Murajov-Amursky Peninsula and islands of the Peter the Great Bay. Thesis Ph.D., Vladivostok, 22 pp. (in Russian). [Горобец К.В. 2004. ФАора листостебельных мхов п-ова Муравьева-Амурского и островов залива Петра Великого (Приморский край). Автореф. Аисс. канд. биол. наук. ВАадивосток. 22 с.].

Hedenas L. \& V.A. Bakalin 2007. Loeskypnum wickesii (Grout) Tuom. Journal of Bryology 29: 200-201.

Hammer, Ø., D.A.T. Harper, P.D. Ryan 2001. PAST: Paleontological Statistics Software Package for Education and Data Analysis. Palaeontologia Electronica 4(1): 1-9.

Huttunen, S., O. Kuznetsova, M. Li, Y-F. Wang \& M. Ignatov 2015. East Asian origin and Northern Hemisphere diversification in the Brachythecium novae-angliae-complex (Bryophyta). Taxon 64(5):911-930.

Ignatov, M.S. 1993. Moss diversity patterns on the territory of the former USSR. Arctoa 2:13-47.

Ignatov, M.S. 2001. Moss diversity in the Western and Northern Palearctic. Arctoa 10:219-236.

Ignatov, M.S., O.M. Afonina, O.I. Kuznetsova \& E.A. Ignatova 2012. The genus Leptopterigynandrum (Taxiphyllaceae, Bryophyta) in Russia. Arctoa 21: 207-220.

Ignatov M., S. Huttunen, M. Li \& Y-F. Wang 2015. How to know Myuroclada longiramea (Brachytheciaceae, Bryophy- 
ta). Arctoa 24:497-502.

Ignatov, M.S. \& E.A. Ignatova 2009. Two new taxa of Pottiaceae from the Kuril Islands. Arctoa 18:135-140.

Ignatov, M.S., E.A. Ignatova \& V.Ya. Cherdantseva 2009. The genus Neckera (Neckeraceae, Bryophyta) in the Russian Far East. Arctoa 18:177-188.

Ignatov, M.S., E.A. Ignatova, Z. Iwatsuki \& B.C. Tan 1999. Two new moss taxa from the Bureya River, Russian Far East. Arctoa 8:59-68.

Ignatov, M.S., E.A. Ignatova \& A.I. Milutina 2010. A revision of the genus Lindbergia in Russia. Arctoa 19:97-116.

Ignatov, M.S., E.A. Ignatova, D.A. Petelin \& B.F. Khasanov 1990. Materials to the bryoflora of Bureya Reserve (Khabarovsk Territory). Byulleten' Moskovskogo obshchestva Ispytateley Prirody. Otdel Biologicheskiy 95(6):86-96 (in Russian with English summary). [Игнатов M.С., Игнатова Е.А., Петемин А.А., Хасанов Б.Ф. 1990. Материалы к бриофлоре Буреинского заповедника (Хабаровский край) // Бюлметень Московского общества испытателей природы. ОтАел биологический. Т. 95, вып. 6. С. 86-96].

Ignatov, M.S. \& I.A. Milytina 2007 a. A revision of the genus Sciuro-hypnum in Russia (Brachytheciaceae, Bryophyta). Arctoa 16:63-86.

Ignatov, M.S. \& I.A. Milytina 2007 b. Sciuro-hypnum oedipodium and $S$. curtum (Brachytheciaceae, Bryophyta). Arctoa 16:47-61

Ignatov, M.S. \& I.A. Milutina 2010. The genus Brachythecium (Brachytheciaceae, Musci) in Russia: comments on species and key for identification. Arctoa 19:1-30.

Ignatov, M.S., B.C.Tan, Z. Iwatsuki \& E.A. Ignatova 2000. Moss flora of the Upper Bureya River (Russian Far East). Journal of Hattori Botanical Laboratory 88:147-178.

Ignatov, M.S., Suzuki T. \& V.Ya Cherdantseva 2007. Fissidens byalinus (Fissidentaceae, Bryophyta), a new species for Russia. Arctoa 16:123-126.

Ignatova, E.A. 2009. The genus Anoectangium in Russia. Arctoa $18: 167-176$.

Ivanova, E.I., N.E. Bell, O.I. Kuznetsova, H. Lee, M. Park \& M.S. Ignatov 2014. The genus Polytrichastrum (Polytrichaceae) in Russia. Arctoa 23:164-184.

Ignatova, E.A., H.H. Blom, D.V. Goryunov \& I.A. Milyutina 2010. On the genus Schistidium (Grimmiaceae, Musci) in Russia. Arctoa 19:195-233.

Ignatova, E.A., H.H. Blom, O.I. Kuznetsova 2016. Schistidium austrosibiricum sp. nov. and S. scabripilum sp. nov. (Grimmiaceae, Bryophyta) - two closely related species from Asian Russia. Arctoa 25(1):107-115.

Ignatova, E.A., V.Ya. Cherdantseva, O.V. Ivanov, I.V. Kostomarova \& M.S. Ignatov 2013. A preliminary list of mosses of the Botchinsky State Nature Reserve (Russian Far East). Arctoa 22:207-216.

Ignatova, E.A. \& V.E. Fedosov 2008. Dicranum with fragile leaves in Russia. Arctoa 17:63-83.

Ignatova, E.A. \& M.S. Ignatov 2007. Didymodon glaucus Ryan (Pottiaceae, Musci) - the first record from Siberia. Arctoa $16: 139-143$

Ignatova, E.A. \& M.S. Ignatov 2011. The genus Thamnobryum (Neckeraceae, Bryophyta) in Russia. Arctoa 20:137-151.

Ignatova, E.A., M.S. Ignatov, T.I. Koroteeva \& D. Ya Tubanova 2016. New moss records from Sakhalin Province. 7. The Kuril Islands. In: Sofronova E.V. (ed.). New bryophyte records. 6. Arctoa 25:221-222.

Ignatova, E.A., O.I. Kuznetsova \& M.S. Ignatov 2016. Grimmia beringiensis sp. nova (Grimmiaceae, Bryophyta), a putative case of intrageneric hybridization. Arctoa
25(1):69-79.

Ignatova, E.A., L.E. Kurbatova, O.I. Kuznetsova, O.V. Ivanov, J.R. Shevock, B. Carter \& M.S. Ignatov 2015. The genus Scouleria (Bryophyta) in Russia revisited. Arctoa 24:47-66.

Ignatova, E.A., O.I. Kuznetsova, H. Kockinger \& R. Hastings 2008. A preliminary study of Coscinodon (Grimmiaceae, musci) in Eurasia based on morphology and DNA sequence data. Arctoa 17:1-18.

Ignatova E.A. \& J.T. Munoz 2004. The genus Grimmia Hedw. (Grimmiaceae, Musci) in Russia. Arctoa 13:101-182.

Ivanova E.I. \& M.S. Ignatov 2007. The genus Lyellia R.Br. (Polytrichaceae, Bryophyta) in Russia. Arctoa 16:169-174.

Ivanova E.I., M.S. Ignatov, A.I. Milutina \& V.K. Bobrova 2005. On the morphological and molecular differences between Oligotrichum bercinicum and O. falcatum (Polytrichaceae, Bryophyta). Arctoa 14:1-12.

Ivanova, E.I., N.E. Bell, O.I. Kuznetsova, E.A. Ionatova \& M.S. Ignatov 2015. The genus Polytrichum sect. Aporotheca (Polytrichaceae) in Russia. Arctoa 24:67-78.

Kolesnikov, B.P. 1938. Materials to moss flora of central Sikhote-Alin In: Proceedings of the Sikhote-Alin state reserve. Vol. 1, pp. 209-227 (in Russian). [Колесников Б.П. 1938. Материалы к флоре мхов среднего Сихотэ-А^иня // Труды Сихотэ-А^инского государственного заповеАника. Вып. 1. С. 209-227].

Koponen, T., E.A. Ignatova, O.I. Kuznetsova \& M.S. Ignatov 2012. The genus Philonotis (Bartramiaceae, Musci) in Russia. Arctoa 21: 21-62.

Koroteeva T.I., A.V. Fedorova \& M.S. Ignatov 2016. Cyrtobypnum versicolor (Thuidiaceae, Bryophyta) in Russia Arctoa 25: 80-88.

Kuzmina, E.Yu. 2000. Mosses of the upper reaches of the Dlinnaya River (Koryak upland). Novosti Sistematiki Nizshih Rastenii 34:226-235 (in Russian). [Кузьмина Е.Ю. 2000. Аистостебельные мхи верхнего течения р. Алинной (Корякское нагорье) // Новости систематики низших растений. Т. 34. С. 226-235].

Kuzmina, E.Yu., A.I. Maksimov \& V.G. Dirksen 2013. New moss records in Kamchatka Territory. 7. Arctoa 22:257 (in Russian). Кузьмина Е.Ю., А.И. Максимов, Аирксен В.Г. 2013. Новые находки мхов в Камчатском краe. 7. In: Sofronova E.V. (ed.) New bryophyte records. 2. Arctoa. Вып. 22. C. 257].

Kuzmina, E.Yu., T.I. Koroteeva, E.V. Sofronova \& R.R. Sofronov 2014. New moss records in Sakhalin Province. 4. Arctoa 23:235 (in Russian). [Кузьмина Е.Ю., Коротеева Т.И., Софронова Е.В., Софронов Р.Р. 2014. Новые находки мхов в Сахалинской области // Arctoa. Вып. 23. C. 235].

Kuzmina, E.Yu., V.Yu. Neshataeva, V.Yu. Neshataev \& A.P. Korablev 2012. To the bryoflora of the Southwest extremity of Koryak upland (Kamchatka territory, Penezhinsky District). Novosti Sistematiki Nizshib Rastenii 46:256-268 (in Russian with English summary). [Кузьмина Е.Ю., Нешатаев В.Ю., Нешатаева В.Ю., Кораблев А.П. 2012. К бриофлоре юго-западной оконечности Корякского нагорья (Камчатский край, Пенежинский район) // Новости систематики низших растений. Т. 46. С. 256-268].

Kuzmina, E.Yu., V.Yu. Neshataeva \& M.S. Ovcharenko 2012. Bryophytes of mountain tundra of Sinij Dol site. In: Proceedings of Kronotskii state natural biosphere reserve. Issue 4 (E.G. Lobkov, ed.), pp. 19-27, Kamchatpress, Petropavlovsk-Kamchatskii (in Russian). [Кузьмина Е.Ю., Нешатаева В.Ю., Овчаренко М.С. 2012. Мохообразные горных тунар урочища Синий дол // Труды 
Кроноцкого государственного природного биосферного заповедника. Выпуск 4 / под ред. Е.Г. Аобкова. Петропавловск-Камчатский: Камчатпресс. С.19-27].

Lapshina, E.D. \& A.I.Maksimov 2014. Sphagnum tenellum (Sphagnaceae, Bryophyta) in West Siberia. Arctoa 23:70-79.

Lazarenko, A.S. 1940. Leafy mosses of the Soviet Far East. I (Acrocarpae: Andreaeales-Schistostegiales). Botanicheskii Zhurnal Akademii Nauk Ukrainskoi RSR 1(3-4):239-243 (in Ukrainian). [Аазаренко А.С. 1940. Аистяні мохи Рацянського Аалекого Сходу I. Верхоплідні мохи (Acrocarpae: Andreaeales-Schistostegiales) // Ботанический журнал АН УРСР. Т. 1, № 3-4. С. 239-243].

Lazarenko, A.S. 1941 a. Leafy mosses of the Soviet Far East. II. Botanicheskii Zhurnal Akademii Nauk Ukrainskoi RSR 2(1):51-95. (in Ukrainian). [Аазаренко A.C. 1941. Аистяні мохи Рацянського Аацекого Сходу II. Acrocarpae: Orthotrichales-Eubryales; Pleurocarpae: Isobryales-Hypnobryales (Theliaceae-Leskeaceae) // Ботанический журнал АН УРСР. Т. 2, № 1. С. 51-95].

Lazarenko, A.S. 1941 b. Leafy mosses of the Soviet Far East. III. Thuidiaceae-Brachytheciaceae. Botanicheskii Zhurnal Akademii Nauk Ukrainskoi RSR 2(2):271-308 (in Ukrainian). [Аазаренко А.С. 1941. Аистяні мохи Радянського Аалекого Сходу III. Thuidiaceae-Brachytheciaсеае // Ботанический журнал АН УРСР. Т. 2, № 2. C. 271-308].

Lazarenko, A.S. 1945. Leafy mosses of the Soviet Far East. IV. Entodontaceae-Hylocomiaceae. Botanicheskii Zhurnal Akademii Nauk Ukrainskoi RSR 2(3-4):185-216 (in Ukrainian). [Аазаренко А.С. 1945. Аистяні мохи РаАянського Аалекого Сходу IV. Entodontaceae-Hylocomiaceae // Ботанический журнац АН УРСР. Т. 2, № 3-4. C. 185-216].

Lazarenko, A.S. 1946. Bryological notes. Botanicheskii Zhurnal Akademii Nauk Ukrainskoi RSR 3(3-4):61-63 (in Ukrainian) [Аазаренко А.C. 1946. Бріологічні нотатки // Ботанический журнал АН УРСР. Т. 3, № 3-4. C. 61-63].

Lindberg, S.O. 1872. Contributio ad floram cryptogamam Asiae Boreali-Orientalis. Acta Societatis Scientiarum Fennicae 10: 223-258.

Maksimov, A.I. 2007. Sphagnum imbricatum complex (Sphagnaceae, Bryophyta) in Russia. Arctoa 16:25-34.

Maksimov, A.I., V.E. Fedosov \& E.A. Ignatova 2016. Sphagnum beringiense (Sphagnaceae, Bryophyta) in Russia. Arctoa 25: 102-106.

Maksimov A.I. \& E.A. Ignatova 2008. Sphagnum alaskense (Sphagnaceae, Bryophyta), a new species for Russia. Arctoa $17: 109-112$.

Maksimov, A.I. \& E.S. Koryagina 2013. New moss records in Amur Province. 1. Arctoa 22:256-257 (in Russian). [Максимов А.И., Корягина Е.С. 2013. Новые находки мхов в Амурской об̆ласти. 1. In: Sofronova E.V. (ed.) New bryophyte records. 2 // Arctoa. Вып. 22. C. 256257].

Malashkina, E.V. 2012 a. New moss records from Magadan Province. 3. In: Sofronova E.V. (ed.) New bryophyte records. 1. Arctoa 21:295.

Malashkina, E.V. 2012 b. New moss records from Primorsky Territory. 2. In: Sofronova E.V. (ed.) New bryophyte records. 1. Arctoa 21:296.
Nyushko T.I., E.A. Ignatova \& M.S. Ignatov 2008. Contribution to moss flora of the Kuril Islands (Russian Far East). Arctoa 2008. 17:165-168.

Omelko, A.M., V.V. Yakubov, V.A. Bakalin, A.V. Velikanov, V.Ya. Cherdantseva, I.F. Skirina, A.N. Yakovleva \& P.V. Krestov 2010. Plant cover of the Mountains Lanzhinskiye Gory (Okhotia). V.L. Komarov Memorial Lectures 57:103-163 (in Russian with English summary). [Оме Аько А.М., Якубов В.В., Бакалин В.А., Великанов А.В., Черданцева В.Я., Скирина И.Ф., Яковлева А.Н., Крестов П.В. 2010. Растительный покров Аанжинских гор (Охотия) // Комаровские чтения. Т. 57. С. 103-163].

Otnyukova T.N., E.A. Ignatova, M.S. Ignatov \& V.E. Fedosov 2004. New records of Tortella alpicola Dix. in Eurasia. Arctoa 13:197-201

Pisarenko, O.Yu. 2015 a. Mosses of the Bolshoi Annachag Range (Magadan Province, Russian Far East). Arctoa 24: 187-193.

Pisarenko, O.Yu. 2015 b. New moss records from Magadan Province. 4. Sofronova E.V. (ed.) New bryophyte records. 4. Arctoa 24:252-255.

Pisarenko, O.Yu. 2015 c. To the bryoflora of Magadan Province (the Russian Far East). In: Proceedings of the international bryolodical conference dedicated to 100th anniversary from A.L. Abramova birthday (St Petersburg, 12-16 October 2015), pp. 109-113, LETI, St-Peterburg (in Russian). [Писаренко О.Ю. 2015. К бриофлоре Магаданской области (Российский Аальний Восток) // Материалы межАународной бриологической конференции, посвященной 100-летию со Аня рождения А. $\Lambda$. Абрамовой (Санкт-Петербург, 12-16 октября 2015 г.). СПб: ИзА-во “АЭТИ". С. 109-113].

Savich-Lyubitskaya, L.I. 1949. To revision of the moss flora of the Far East. Botanicheskii Zhurnal 34(2):210-211 (in Russian). [Савич-Аюбицкая А.И. 1949. К ревизии Аальневосточной фморы мхов. I. // Ботанический журнал. T. 34, № 2. С. 210-211].

Tubanova, D.Ya., D.V. Goryunov, E.A. Ignatova \&M.S. Ignatov 2010. On the taxonomy of Dicranum acutifolium and D. fuscescens complexes (Dicranaceae, Bryophyta) in Russia. Arctoa 19:151-164.

Tubanova D.Ya. \& E.A. Ignatova 2011. A new species of Dicranum (Dicranaceae, Bryophyta) from Asiatic Russia. Arctoa 20:183-190.

Yakovchenko, L.S., I.A. Galanina, V.A. Bakalin \& E.V. Malashkina 2013. Bryophytes and lichens of old-growth forests in lower Amur River area. V.L. Komarov Memorial Lectures 60:8-68 (in Russian with English summary). [Яковченко А.С., Галанина И.А., Бакалин В.А., Мамашкина Е.В. 2013. Мохообразные и мишайники малонарушенных месных сообществ в нижнем Приамурье (Российский Аальний Восток) / / Комаровские чтения. Т. 60. С. 8-68].

Zverev, A.A. 2007. Information technologies in studies of plant cover. Tomsk, 304 pp. (in Russian). [Зверев A.A. 2007. Информационные технологии в исследованиях растительного покрова. Томск. 304 с.].

Zolotov V.I. \& O.M. Afonina 2015. New moss records from Chukotka Autonomous District. 2. In: Sofronova E.V. (ed.) New bryophyte records. 4. Arctoa 24:252. 